(RESEARCH ARTICLE)

\title{
Effect of aqueous extract of Azadirachta indica on rifampicin- induced jaundice in rabbits
}

Tunji Akande 1, Timothy Olugbenga Ogundeko 2, *, Solomon Oyewale Opajobi 1, Samaila Garba Yaura ${ }^{1}$, Isiaiah Iorkyase Idyu ${ }^{3}$ and James Olasunkanmi Ayorinde ${ }^{4}$

${ }^{1}$ Department of Medical Laboratory Sciences, Faculty of Basic Medical Sciences, Bingham University, Karu, Nigeria.

${ }^{2}$ Department of Pharmacology \& Therapeutics, College of Medicine and Health Sciences, Bingham University, Jos, Nigeria.

${ }^{3}$ Department of Pharmacology, Faculty of Pharmaceutical Sciences, University of Jos, Nigeria.

${ }^{4}$ Department of Pest management Technology, Federal College of Forestry, Jos, Nigeria.

Publication history: Received on 13 November 2020; revised on 20 November 2020; accepted on 21 November 2020

Article DOI: https://doi.org/10.30574/wjarr.2020.8.2.0422

\begin{abstract}
High rate of dependence on medicinal plants for maintenance of health care needs over the decades in communities all over the world especially in Africa and Asia needs adequate scientific verification and authentication. Liver related diseases have however become a global problem. Jaundice was established on 9 of a total population of 12 rabbits of mixed sex, weighing $1.50 \mathrm{~kg}-2.34 \mathrm{~kg}$ using an overdose pretreatment of Rifampicin (300mg/ kg bw) P.0. After 3 days, the Animals were administered with various doses of aqueous extract of Azadirachta indica $(600,750,900 \mathrm{mg} / \mathrm{kg} \mathrm{bw})$ P.O for each group of rats - A, B, C and D (control), after which the animals were bled via marginal ear vein at zero hour, $7^{\text {th }}$ and $14^{\text {th }}$ days and the blood used for the following assays: Alkaline Phosphatase, Acid Phosphatase, Total Bilirubin, Conjugated Bilirubin and Alanine Transaminase. Experimental animals exhibited lack of appetite, reduced activity, scratching of the body, emesis, yellow coloration of the sclera, light-colored stool and a little dark urine over time. There was also increase in the levels of the biochemical parameters as the day increased. Aqueous extract of Azadirachta indica (Neem) exhibited increasing elevated levels of Alkaline Phosphatase (ALP), Acid Phosphatase (AP), Total Bilirubin (T/Bil), Conjugated Bilirubin (Conj/Bil), and slightly in Alanine Transaminase (ALT), thus exerted elevated hepatotoxicity on Rifampicin-induced Rabbits. Therefore, the traditional use of Azadirachta indica in management of jaundice should be discontinued.
\end{abstract}

Keywords: Azadirachta indica; Rabbit; Bilirubin; Jaundice; Rifampicin

\section{Introduction}

Herbs and foods may stimulate or assist the immune system to conquer sickness, injury, fatigue or a variety of maladies in human life. Many communities in Africa have much elaborated plant knowledge [1]. Medicinal plants are globally valuable sources of new drugs $[2,3,4]$. The term 'crude drugs of natural or biological origin' is used by pharmacists and pharmacologists to describe whole plants or parts of plants which have medicinal properties [5].

Azadirachta indica A. juss (AI; Family: Meliaceae) is a popular medicinal plant originally grown in India [6], but is now being cultivated in almost every part of the world including Nigeria [7].

Names for this plant in various languages include Hausa - Darbejiya, Dogonyaro, Bedi, Arabic - Neeb, Azad-darakhulhind, Shajarat Alnnim, English - Margosa, Neem Tree, French - Azadirac de l'Inde, margosier, margousier, German Indischerzedrach, Grossblaettigerzedrach [8]. Azadirachta indica is being used for various purposes. Neem is now used

\footnotetext{
* Corresponding author: Timothy Olugbenga Ogundeko

Department of Medical Laboratory Sciences, Faculty of Basic Medical Sciences, Bingham University, Karu, Nigeria. 
as an active ingredient in certain popular such as tooth paste in Germany and India since it prevents tooth decay and heals inflammation of gums, as chewing stick for toiletries [9], and in antidesertification [10, 11]. Very young leaves of Azadirachta indica and r. Juss. (Meliaceae - 'Vembu') are fried with CarumnothumCl. (Apiaceae - 'Omam') salt, powdered and given in milk in order to cure jaundice [12]. The divine tree neem (Azadirachta indica) is mainly cultivated in the Indian subcontinent. Neem has been used extensively by humankind to treat various ailments before the availability of written records which recorded the beginning of history [13]. Jaundice is one of the most common medical condition affecting infants, children, and adults. Jaundice is not a disease but it is a visible sign and symptom of liver disease which occurs when there is an increase in the amount of bilirubin circulating in the blood due to the abnormal metabolism and excretion in the urine [14]. In spite of tremendous advances made in allopathic medical practices, herbs still play an important role in the management of various liver diseases. A large number of plants and formulations have been claimed to have hepato-protective activity [15]. Medicinal plants are being used long ago by our ancestors for the treatment of jaundice. At the present era, consumption of these herbal medicines is increasing at a high speed, due to its less or no side effect and cost-effectiveness as compared to synthetic medicines [14]. Rifampicin caused a significant increase in the total cholesterol, triglycerides and LDL-cholesterol, a significant decrease in HDL-cholesterol as well as significant increase in serum AST, ALT, bilirubin and urea levels in an investigation to evaluate the effect of two oral administered antibiotics (Rifampicin and Tetracycline) on some physiological parameters in the serum of male albino rats where histopathological alterations in liver and kidney examined [16]. Rifampicin is associated with frequent adverse reaction of which jaundice is most notable [17]. Serum bilirubin has also been proposed to be a useful marker to differentiate cardioembolic stroke from other subtypes of strokes [18]. Recently, high serum bilirubin levels were found to be significantly associated with the fatal outcome in patients infected with Ebola virus [19].

High rate of dependence on medicinal plants for maintenance of health care needs over the decades in communities all over the world especially in Africa and Asia need urgent attention as various claims on the use of plants by the communities differ while some are same even with the challenge of proper dosage, formulation and standardization before administration. Several works were reported on the utility of plants for the treatment of diabetes and jaundice $[20,21]$. Continual and further studies on herbal preparations should always be in the front burner of medical and pharmaceutical research [22], thus further need to authenticate the use of Azadirachta indica in the treatment of jaundice. This study aimed to evaluate the effect of aqueous leave extract of Azadirachta indica on Rifampicin jaundice induced rabbits.

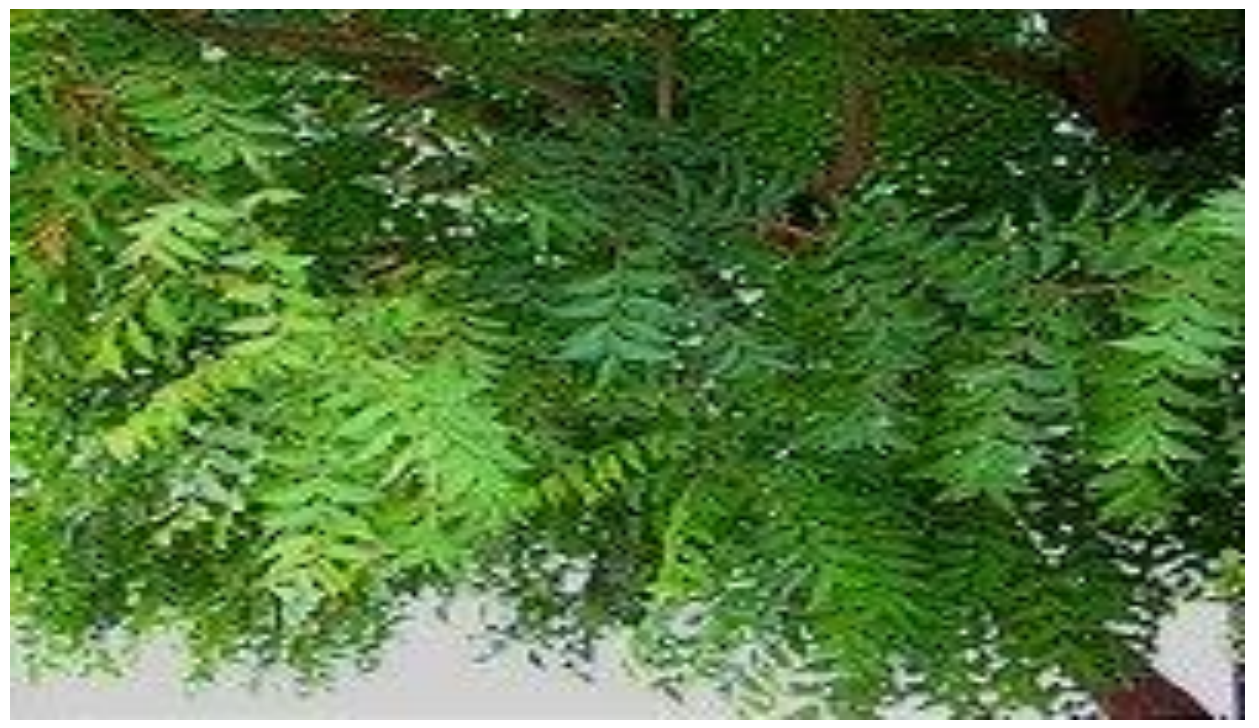

Figure 1 Neem tree [23]

\section{Material and methods}

\subsection{Plant collection and extraction}

Fresh leaves of Azadirachta indica was collected from Rayfield area of Jos- plateau state Nigeria. This was identified and authenticated at the Federal College of Forestry, Jos, Nigeria. The leaves were thoroughly washed with clean water and shredded. After this, $300 \mathrm{~g}$ was weighed into $250 \mathrm{ml}$ of distilled water and grinded in an electric blender in order to 
obtain a homogeneous mixture. This was then sieved with Whatman (size12) filter paper, while the filterate was weighed and kept in the refrigerator until use.

\subsection{Animal preparation and drug administration}

12 rabbits of mixed sex, weighing between $1.50 \mathrm{~kg}$ and $2.34 \mathrm{~kg}$ were collected from the Animal House Unit of the Department of Pharmacology and Therapeutics, Bingham University, Jos, Nigeria. The animals were maintained with pelleted feed and water (ad libitum), optimum light and temperature in accordance with the principles and guidelines of handling laboratory animals according to [24]. The animals were divided into four groups of three animals each, kept in cages for 7 days, starved 24 hours prior to experiment for acclimatization and were administered with Rifampicin and aqueous extract of Azadirachta indica. Groups 1-3 were induced with Jaundice using Rifampicin at 300mg/ kg, P.0 for 3 consecutive days in order elevate the bilirubin (conjugated and total) and alkaline phosphates levels. On day 4, aqueous extract of Azadirachta indica (900mg/kg, P.0) was administered. However, group 4 served as control. Furthermore, feacal and urine appearances and animal behaviours were observed both at beginning and end of experiment.

\subsection{Blood sample collection}

The animals were all bled at zero hour and 3 days after Rifampicin administration as well as and day 7 and 14 post Azadirachta Indica extract administration. $5 \mathrm{ml}$ of blood sample was collected via the marginal ear vein of each animal into dry centrifuged tubes and were allowed to retract for one hour, the sera formed was centrifuged at $3000 \mathrm{rpm}$ for 5 minutes to obtain a clear serum which was then transferred into plain EDTA bottles using pipette.

\subsection{Biochemical Analysis}

The following investigations were carried out to determine the serum concentrations of serum bilirubin according to [25], serum alkaline phosphatase and serum aminotransferases (AST and ALT) using commercial diagnostic kits by Randox UK.

\subsection{Statistical analysis}

Descriptive methods were used. All data were expressed as mean \pm SEM.

\section{Results and discussion}

Behavioural manifestations of the animals in the experimental group (A, B and C) starting from the first 5 days include refusal to eat, reduced activity thus became unusually reserved robbing of body against the cage and scratching of the body. Others include Emesis, yellow coloration of the sclera, light-colored stool and a little dark urine within day. Group $\mathrm{D}$ animals however showed none of the mentioned signs and symptoms. The aforementioned portrayed that jaundice was established in the experimental animals. However, results increase level in of hepatotoxicity in the animals via the biochemical investigations as the number of days increased. This agrees with [26], who stated that Rifampicin is associated with frequent adverse reaction of which jaundice is most notable. Similarly, Rifampicin produces many metabolic and morphological aberrations in the liver due to the fact that the liver is the main detoxifying site for these anti-tubercular drugs $[27,26]$.

Having induced hepatotoxicity on the experimental animals, biochemical analysis revealed increased level of alkaline phosphatase in the presence of the aqueous extract of Azadirachta indica with time as seen in from baseline to week 2 , with group $C$ having the highest level followed by B and A respectively - Table 2; Figure 2. Same trend was observed in the Total Bilirubin level while the control group remained unchanged - Table 2; Figure 3 and that of the Conjugated Bilirubin level, but the animals had severe diarrhea while one mortality was recorded - Table 2; Figure 4.

Furthermore, there was a slight difference with the level of alanine Transaminase despite non-the-less, it followed same pattern of increasing levels of the biochemical parameters from baseline -week 2 - Table 2; Figure 5. The characteristic of the aqueous extract of Azadirachta indica in this case is in contrary with the study by [28] who reported that the ALT profile of rabbits treated with $25 \%, 50 \%$ and $75 \%$ C. lemon juice were extremely significantly different when compared to the control group at $\mathrm{P}<0.001$ and that of [29] who also reported T. cardifolia stem and leaves extract showed hepatoprotective action against lead-induced hepatotoxicity in mice due to the scavenging of free radicals generated by the lead toxicity. The forgoing is an indication of a detrimental effect on the biochemical functions of the liver of the experimental animals. 
Table 1 Body weight and volume of drugs and extract administered per Animal

\begin{tabular}{|c|c|c|c|c|c|c|}
\hline Group & Animal & $\begin{array}{l}\text { Body } \\
\text { weight }(\mathrm{Kg})\end{array}$ & $\begin{array}{l}\text { Required } \\
\text { dose }(\mathrm{Mg} / \mathrm{Kg})\end{array}$ & Volume (ml) & $\begin{array}{l}\text { Required } \\
\text { dose }(\mathrm{Mg} / \mathrm{Kg})\end{array}$ & Volume (ml) \\
\hline \multirow[t]{3}{*}{ A } & I & 1.80 & 300 & 1.8 & 600 & 3.6 \\
\hline & II & 2.10 & 300 & 2.1 & 600 & 4.0 \\
\hline & III & 1.90 & 300 & 1.9 & 600 & 3.8 \\
\hline \multirow[t]{3}{*}{ B } & I & 1.85 & 300 & 1.9 & 750 & 4.6 \\
\hline & II & 2.34 & 300 & 2.3 & 750 & 5.9 \\
\hline & III & 2.0 & 300 & 2.0 & 750 & 5.0 \\
\hline \multirow[t]{3}{*}{$\mathrm{C}$} & I & 1.50 & 300 & 1.5 & 900 & 4.5 \\
\hline & II & 1.60 & 300 & 1.6 & 900 & 4.8 \\
\hline & III & 2.01 & 300 & 2.0 & 900 & 6.0 \\
\hline \multirow[t]{3}{*}{$\mathrm{D}$} & I & 1.85 & 1.8 & - & - & - \\
\hline & II & 1.68 & 1.7 & - & - & - \\
\hline & III & 2.01 & 2.0 & - & - & - \\
\hline
\end{tabular}

Table 2 SEM of biochemical parameters of the blood samples of Azadirachta indica treated jaundiced Rabbits

\begin{tabular}{|c|c|c|c|c|}
\hline \multirow{2}{*}{$\begin{array}{l}\text { Biochemical } \\
\text { parameters }\end{array}$} & \multirow[t]{2}{*}{ Group } & \multirow[t]{2}{*}{ Baseline } & $1^{\text {st }} \quad$ Week & $2^{\text {nd }} \quad$ Week \\
\hline & & & Administration & Administration \\
\hline \multirow{4}{*}{$\begin{array}{l}\text { Alkaline } \\
\text { phosphotase }\end{array}$} & A & $44.5 \pm 0.0$ & $54.3 \pm 1.0$ & $54.0 \pm 1.0$ \\
\hline & B & $44.0 \pm 0.0$ & $55.0 \pm 1.0$ & $58.0 \pm 1.2$ \\
\hline & $\mathrm{C}$ & $43.6 \pm 0.4$ & $54.0 \pm 0.9$ & $67.0 \pm 1.5$ \\
\hline & $\mathrm{D}$ & $45.6 \pm 0.0$ & $46.7 \pm 0.1$ & $46.3 \pm 0.3$ \\
\hline \multirow[t]{4}{*}{ Total bilirubin } & A & $5.1 \pm 0.0$ & $8.6 \pm 0.7$ & $10.2 \pm 0.4$ \\
\hline & B & $5.1 \pm 0.0$ & $8.7 \pm 0.2$ & $15.3 \pm 0.8$ \\
\hline & $\mathrm{C}$ & $5.1 \pm 0.0$ & $8 . \pm 0.2$ & $17.2 \pm 0.9$ \\
\hline & $\mathrm{D}$ & $5.1 \pm 0.0$ & $5.1 \pm 0.0$ & $5.1 \pm 0.0$ \\
\hline \multirow{4}{*}{$\begin{array}{l}\text { Conjugated } \\
\text { bilirubin }\end{array}$} & A & $9.0 \pm 0.2$ & $13.4 \pm 0.6$ & $15.5 \pm 0.4$ \\
\hline & B & $9.45 \pm 0.2$ & $19.0 \pm 1.0$ & $20.0 \pm 2.0$ \\
\hline & $\mathrm{C}$ & $9.20 \pm 0.2$ & $20.0 \pm 2.0$ & $24.0 \pm 1.2$ \\
\hline & $\mathrm{D}$ & $8.0 \pm 0.0$ & $8.0 \pm 0.0$ & $8.0 \pm 0.0$ \\
\hline \multirow{4}{*}{$\begin{array}{l}\text { Alanine } \\
\text { transaminase }\end{array}$} & A & $44.0 \pm 0.1$ & $47.0 \pm 0.7$ & $48.5 \pm 0.6$ \\
\hline & $\mathrm{B}$ & $43.5 \pm 0.1$ & $46.0 \pm 0.2$ & $49.2 \pm 0.4$ \\
\hline & $\mathrm{C}$ & $43.5 \pm 0.1$ & $48 \pm 0.7$ & $49.5 \pm 0.4$ \\
\hline & D & $43 \pm 0.0$ & $43 \pm 0.0$ & $43 \pm 0.0$ \\
\hline
\end{tabular}


World Journal of Advanced Research and Reviews, 2020, 08(02), 205-212

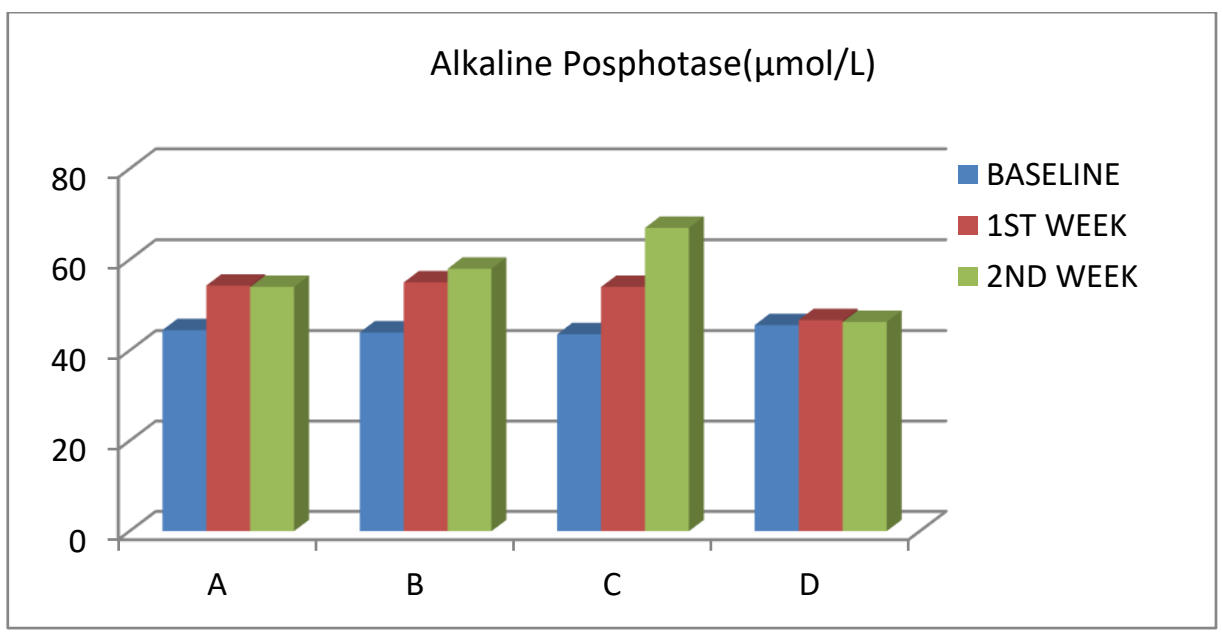

Figure 2 Alkaline phosphatase

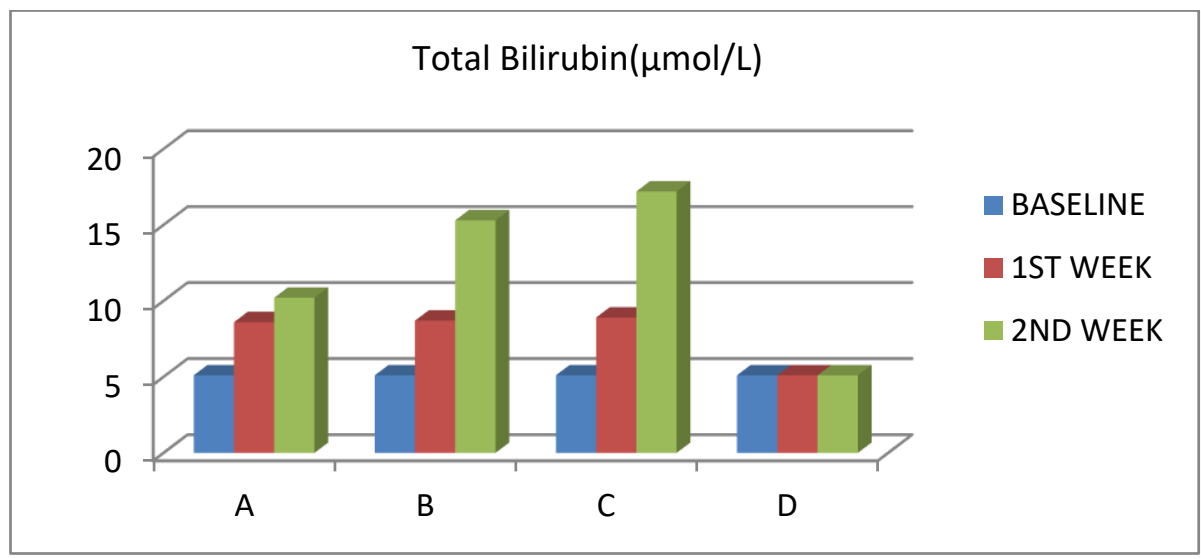

Figure 3 Total Bilirubin

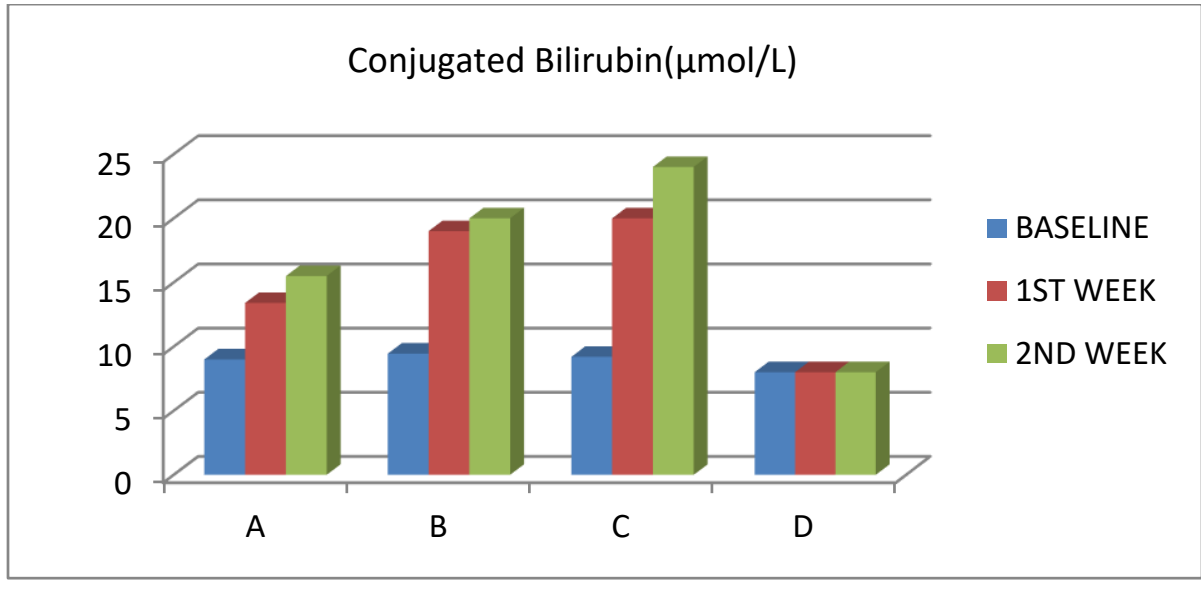

Figure 4 Conjugated bilirubin 


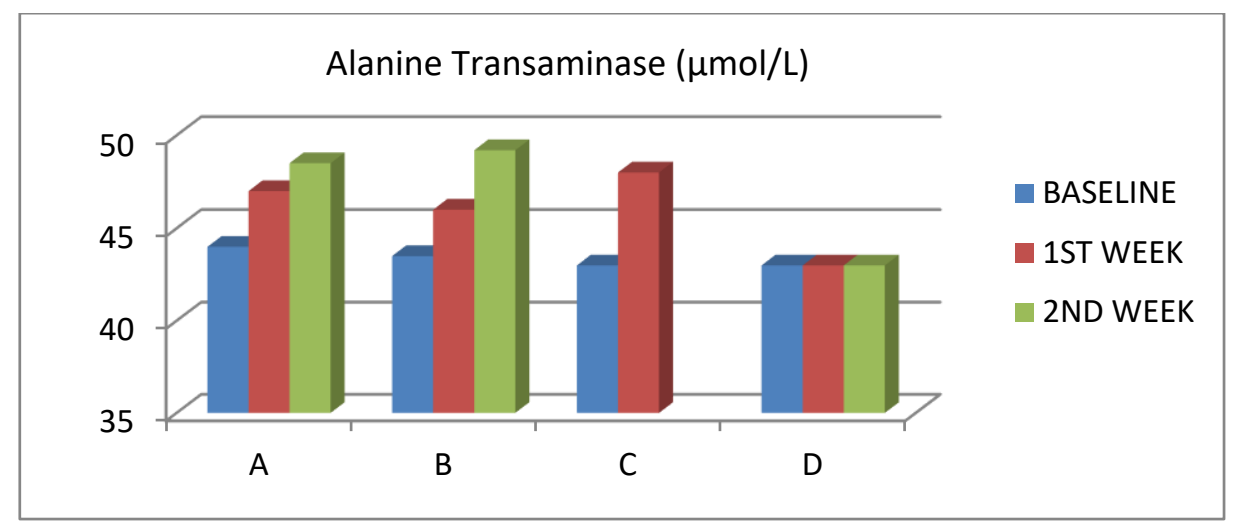

Figure 5 Alanine Transaminase

\section{Conclusion}

Aqueous extract of Azadirachta indica (Neem) exhibited increasing elevated levels of Alkaline Phosphatase (ALP), Acid Phosphatase (AP), Total Bilirubin (T/Bil), Conjugated Bilirubin (Conj/Bil), and slightly in Alanine Transaminase (ALT), thus exerted elevated hepatotoxicity on Rifampicin-induced Rabbits. Therefore, the traditional use of Azadirachta indica in management of jaundice should be discontinued.

\section{Compliance with ethical standards}

\section{Acknowledgments}

Sincere thanks to Alexis, Alexander and Victoria Ogundeko for typesetting and statistical analysis, Mr. Sam Ajayi, Mr. Jones Ihiemekpen and Mr. Mike Lawal for appropriate counsel.

\section{Disclosure of conflict of interest}

Authors declare no conflict of interest.

\section{Statement of ethical approval}

Authors are licensed to handle laboratory animals. Animal care research protocols were carried out based on the principles and guidelines in compliance with the guide for the care and use of laboratory animals as reported in Tuhin et al., (2017) [30].

\section{References}

[1] Barrow EGC. The Dry Lands of Africa: Local Participation in Tree Management. Initiative Publishers, Nairobi. 1996.

[2] Chacko SM, Thambi PT, Kuttan R, Nishigaki I. Beneficial effects of green tea: a literature review. Chin Med. 2010; 5:13.

[3] Chen SL, Yao H, Han JP, Liu C, Song JY, Shi LC, Zhu YJ, Ma XY, Gao T, Pang XH, Luo K, Li Y, Li XW, Jia XC, Lin YL, Leon C. Validation of the ITS2 region as a novel DNA barcode for identifying medicinal plant species. PLOS ONE. 2010; 5:e8613.

[4] Nalawade SM, Sagare AP, Lee CY, Kao CL, Tsay HS. Studies on tissue culture of Chinese medicinal plant resources in Taiwan and their sustainable utilization. Bot Bull Acad Sin. 2003; 44:79-98.

[5] Sofowora A, Ogunbodede E, Onayade A. The Role and Place of Medicinal Plants in the Strategies for Disease Prevention. Afr J Tradit Complement Altern Med. 2013; 10(5):210-229.

[6] Ofem OE, Ikpi DE, Essien NM. Increased bile flow rate and altered composition of bile induced by ethanolic leaf extract of Azadirachta indica (neem) in rats. Niger J Exp Clin Biosci. 2013; 1:18-22. 
[7] Sonibare MO, Isiaka AO, Taruka WM, Williams NS, Soladoye M, Emmanuel O. Constituents of Neem leaves. Nat Prod Commu. 2006; 23-6.

[8] http://www.flowersofindia.net/catalog/slides/Neem.html

[9] Chaudhari AB, Kuwar AS, Mahulikar PP, Hundiwale DG, Kulkarni RD, Gite VV. RSC. Development of anticorrosive two pack polyurethane coatings based on modified fatty amide of Azadirachta indica Juss oil cured at room temperature - a sustainable resource, Advances. 2014; 17866-17872, D0I: 10.1039/c4ra01880j.

[10] Bhambal, A, Sonal K, Sudhanshu S, Manish J. "Comparative effect of neemstick and toothbrush on plaque removal and gingival health - A clinical trial". Journal of Advanced Oral Research. 2011; 2 (3):51-56. ISSN 2229-4120.

[11] Callahan C. "Uses Of Neem Datun For Teeth". Livestrong.com.Demand Media. 2010. Retrieved 16 July 2013.

[12] Shanmugam S, Manikandan, K and RajendranK. "Ethnomedicinal Survey of Medicinal Plants Used for the Treatment of Diabetes and Jaundice Among the Villagers of Sivagangai District, Tamilnadu," Ethnobotanical Leaflets.2009; 2(1): 22.

[13] Venugopalan K, Santhosh KV. Neem (Azadirachta indica): Prehistory to contemporary medicinal uses to humankind. Asian Pac J Trop Biomed. 2013; 3(7):505-514.

[14] Vandana J, Pushpendra, Patel S, Singh C. Plants used for the treatment of icterus (jaundice) in Central India: A review. Annals of Hepatology. 2019; 18 (5): 658-672.

[15] Jyotsana Sharma, Sumeet Gairola, R.D.Gaur, R.M.Painuli. The treatment of jaundice with medicinal plants in indigenous communities of the Sub-Himalayan region of Uttarakhand, India. Journal of Ethnopharmacology. 2012; 143 (1):262-291.

[16] Shabana MB, Ibrahim HM, Khadre SEM, and Elmam MG. Influence of rifampicin and tetracyclin administration on some biochemical and histological parameters in albino rats: The Journal of Basic and Applied Zoology. 2012; 65: 299-308.

[17] Scheuer PJ: Rifampicin hepatitis. The Lancet. 1974; 421-425.

[18] Lin SP, Lin PY, Jiang HL, et al. Is serum total bilirubin useful to differentiate cardioembolic stroke from other stroke subtypes? Neurol Res. 2016; 37:727-31.

[19] Cournac JM, Karkowski L, Bordes J, et al. Rhabdomyolysis in Ebola Virus Disease. Results of an Observational Study in a Treatment Center in Guinea. Clin Infect Dis. 2016; 62:19-23. [Crossref] [PubMed]

[20] Katz, S. R.; Newman, R. A. and Lansky, E. P. Punicagranatum: Heuristic Treatment for Diabetes Mellitus. J. Med. Food. 2007; 10 (2):213 - 217.

[21] Leach, M. J. Gymnemasylvestre for Diabetes Mellitus: A Systematic Review. The Journal of Alternative and Complementary Medicine. 2007; 13 (9):977 - 983.

[22] Idyu II, Deshi EF, Idyu VC, Ogundeko TO. The Anti-diarrhoeal Effect of Ethanolic-Bark Extract of Sterculia setigera in Mice. Asian J. Sci.Tech. 2015; 6 (05):1397-1400.

[23] www.dreamstime.com - Accessed 15-04-2020

[24] Builders MI, Builders PF and Ogundeko TG. Anti-Ulcer activity of the stem bark of African locust bean tree in rats, Int. J. Phytotherapy Research. 2016; 6 (4):11-19.

[25] Jendrassik L, Grof, V. Estimation of direct and total Bilirubin. BiochemischeZeitschrift. 1938; 297:81-89.

[26] Scheuer PJ, Summerfield JA, Lal S, Sherlock S. Rifampicin hepatitis. A clinical and histological study. Lancet. 1974; 1(7855):421-5.

[27] Santhosh S, Sini TK, Anandan R, Mathew PT. Hepatoprotective activity of chitosan against isoniazid and rifampicin-induced toxicity in experimental rats: Eur. J. Pharmacol. 2007; 572:69-73.

[28] Solomon IP, Oyebadejo SA, Ebenso IE, Otoho EA. Biochemical Effect of Citruslemon Juice on the Liver of Growing Rabbits (Oryctolagus cuniculus). J AgricVet Sci. 2015; 2(5):356-361p-ISSN2348-8883CScholars Academic and Scientific Publishers

[29] Kumar V, Modi PK, Saxena KK. Exploration of hepatoprotective activity of aqueous extract of Tinospora cordifolia - an experimental study. Asian J Pharm Clin Res. 2013; 6:87-91. 
[30] Tuhin RH, Begum M, Rahman S, Karim R, BegumT, Ahmed SU, Mostofa R, Hossain A, Mohamed Abdel-Daim M, Rayhana Begum R. Wound healing effect of Euphorbia hirta linn. (Euphorbiaceae) in alloxan induced diabetic rats. BMC Complementary and Alternative Medicine. 2017; 17:423. 